\title{
Træk af Draved skovs historie
}

\section{Af Alfred Andersen}

I dette efterladte arbejde af fhv. afdelingsgeolog ved Danmarks Geologiske Undersøgelse, Alfred Andersen, fortælles om den naturhistorisk interessante Draved skov syd for Løgumkloster. Skovens tilhørsforhold til klostret i Løgum omtales, men det er især ulvejagter, tyverier af træ, forbudt græsning i skoven og skovbrande, der behandles. Herigennem gives et levende, kulturhistorisk billede af menneskets forhold til skoven og udnyttelsen af den frem til den moderne skovdrifts indførelse ved midten af 1800-tallet.

\section{Indledning ${ }^{1}$}

Nogle få km syd for Løgumkloster ligger Draved Skov. I dag er den omgivet af vidtstrakte marker, men indtil for få menneskealdre siden lå der omkring skoven store, svært fremkommelige mose- og hedestrækninger. Skoven ligger tæt ved nordkanten af Kongsbjerg bakkeø, som på dette sted næsten umærkeligt glider over i hedesletten. Bakkeøens moræneler er her dækket af et lag flyvesand af vekslende tykkelse. Det er én af årsagerne til, at jordbundsforholdene $i$ skoven er meget varierende, hvilket igen giver sig udslag $i$ en spændende variation i plantevæksten. Dette $i$ forbindelse med den afsides beliggenhed, som har betydet, at skoven gennem tiderne kun har været udsat for relativt få forstmæssige indgreb, gør Draved skov til en betydelig naturhistorisk seværdighed velegnet til videnskabelige undersøgelser.

Siden 1948 har Danmarks Geologiske Undersøgelse (D.G.U.) løbende foretaget studier i skoven hovedsageligt af botanisk/økologisk art. Således er der flere steder fredede, indhegnede områder, hvor skoven helt får lov til at passe sig selv, og hvor det derfor er muligt at få et indtryk af, hvordan landets oprindelige skov har været og udviklet sig. Endvidere har D.G.U. i samarbejde med Nationalmuseet foretaget skovrydnings- og dyrkningsforsøg, for at få en bedre forståelse af, hvordan de første stenalderbønder tog landet $\mathrm{i}$ besiddelse, ${ }^{2}$ og i mosestrækningerne vest for skoven har der været foretaget botanisk/geologiske undersøgelser i forbindelse med arkæologiske udgravninger af bopladser fra jægerstenalderen, for at give et billede af, hvordan naturforholdene var på dette tidspunkt. ${ }^{3}$

Selv om disse undersøgelser har givet både mange og spændende resultater, skal de dog ikke omtales nærmere her. Opmærksomheden skal i stedet rettes 
mod skoven i en historisk sammenhæng, hvor den absolut heller ikke er uinteressant.

Som nævnt har skoven delvist været omgivet af store mosestrækninger, og det giver sig da også til kende i selve navnet: Drav, som synes at betyde mose eller sump, og ved=skov. Stavemåden har varieret en del i tidens løb, og af ældre afvigende former kendes bl.a. Drowidt, (1263), Drøffuith (1481), Droffuit (1519), Droufvydt (1548) og Drauwit (1704). ${ }^{4}$ I samme forbindelse kan også nævnes, at Kongens Mose $i$ en indberetning fra 1789 kaldes Drogden $^{5}$ hvori forstavelsen formentlig er den samme som i navnet Drowidt (Draved).

Draved skov dækker nu til dags et areal på ca. 200 ha., men i gammel tid har den været betydelig større. Det ældste brugelige kort over egnen er opmålt af Johs. Mejer og stammer fra midten af 1600-tallet (se fig. 1). Det viser, at skoven på den tid strakte sig længere både i nordlig og sydvestlig retning. Nøjagtigere og mere detailleret er dog Videnskabernes Selskabs kort fra o. 1800. Imidlertid har både dette og Mejers kort den ulempe at være tegnet $\mathrm{i}$ en forholdsvis lille målestok, så iagttagelse af enkeltheder ved skoven vanskeliggøres. Bedre i så henseende er et specielt kort over Draved skov fra 1780 (fig. 2), der ved sammenligning med nutidens målebordsblad (fig. 3) ligeledes viser, at skoven dengang havde en noget større udstrækning end nu.

\section{Draved skov i middelalderen.}

Logum Klosters rettigheder i Draved skov

I året 1173 kom cisterciensermunke fra Seem ved Ribe og grundlagde Løgum Kloster ved Bredeå. Fra den første spæde begyndelse voksede det nye kloster op til at blive en magtfaktor på egnen. De skiftende abbeder var ikke blot dygtige prælater, men også gode til at skaffe klosteret jordisk gods. Også Draved skov, der vel oprindelig var en slags ingenmandsland, var de stærkt interesserede i. Skoven var dengang større end nu, idet den ikke blot bestod af det nuværende, men også af tilgrænsende arealer, f.eks. det sydøst for liggende Moskær (Moskiær, Mossekier), som da var træbevokset.

Det første brev (fra 1263), ${ }^{6}$ hvori Draved vides at være omtalt, er skrevet af hertug Erik, en søn af kong Abel, og begynder således: „Erik, af Guds nåde hertug i Jylland, til alle, der ser dette brev. Hilsen evindelig med Gud.» Hertugen har sendt sin drost, Jens Hvidding, for at afgøre en trætte mellem Løgum Kloster og en vis Jacob Thuesen om Draved skov, "som kaldes Stuff «."

Sagen afgøres således, at munkene »tilfulde skal have deres gamle 


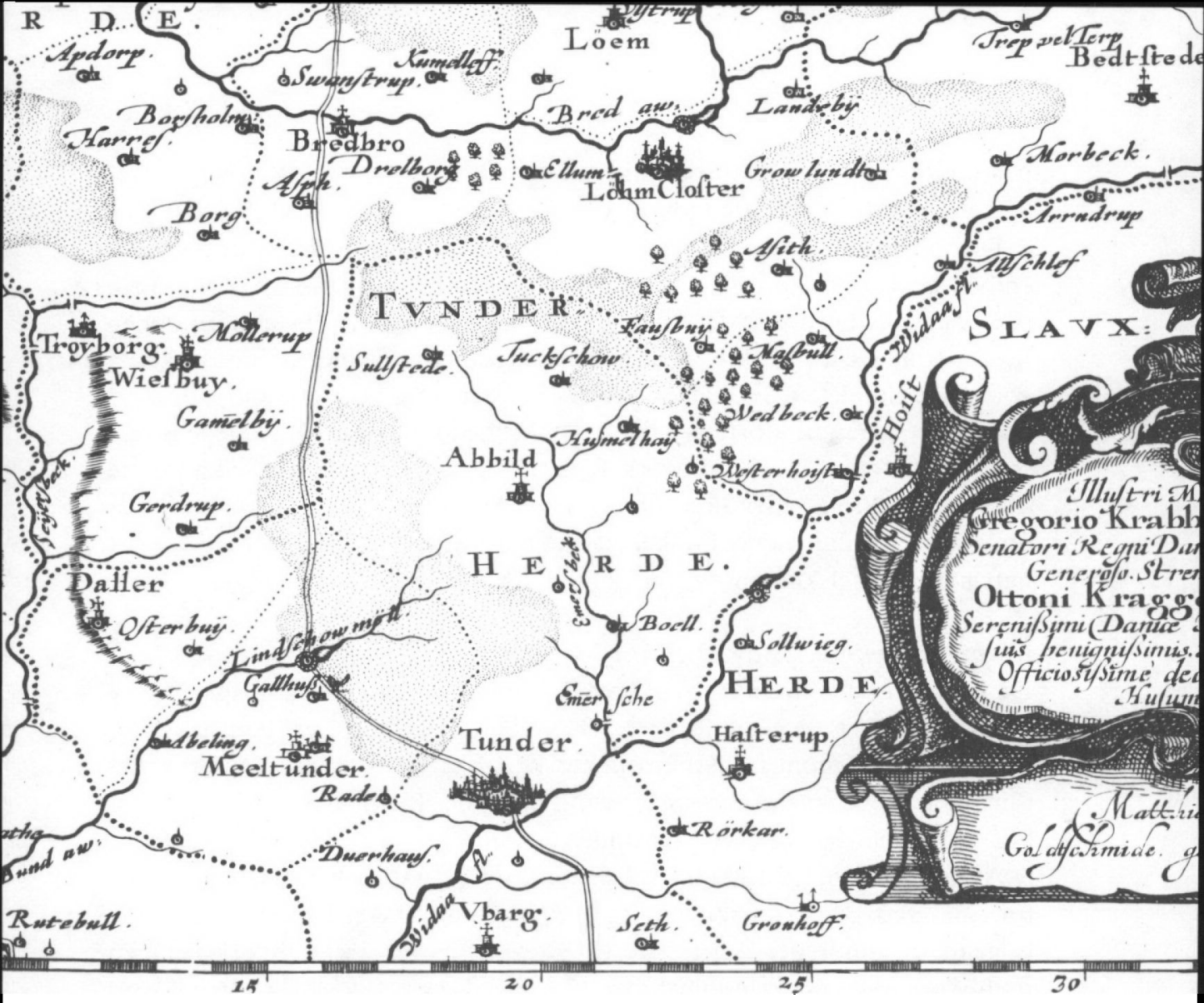

Fig. 1. Udsnit af Johs. Mejers kort over Tonder-egnen fra midten af 1600-tallet. (Efter Mejer og Danckwert: Newe Landesbeschreibung der zwei Hertzogthümer Schleswig und Holstein, 1652).

besiddelse i den nævnte skov og eje den frit til evig tid. Og på den anden side skal næunte Jacob $\mathrm{i}$ lige måde nyde sin besiddelse til evig tid og ikke $\mathrm{i}$ fremtiden hindre de nævnte munke i dette«. Det synes altså, som om Jacob Thuesen i forvejen ejer en del af skoven.

Naste gang, Draved omtales skriftligt, er $\mathrm{i}$ året $1280 \mathrm{og}$ endda $\mathrm{i}$ hele to breve, som åbenbart drejer sig om samme sag.

Først et åbent brev skrevet af biskop Tyge af Ribe, som søger at komme munkene i Løgum Kloster til undsætning. Disse har åbenbart tidligere købt en fjerdedel af "Alslev Otting i Draved skov af Mark Rød i Løgumkloster, men nu er han død, og da hans arvinger ikke vil anerkende munkenes ret til den nævnte skovpart, så "pålægger vi næunte Mark Røds arvinger, at de hjemler ovennavnte munke bemeldte fjerdedel af Alslev Otting, ${ }^{8}$ hvilket er deres pligt, eller at de inden femten dage, efter at dette brev er læst, ikke undlader at tilbagebetale dem deres købesum tillige med en tilbørlig og 
passende erstatning. I modsat fald må de vide, at de fra da af er undergivet kirkeligt interdikt ved dette brev."

Det andet brev, der ligeledes er skrevet af biskop Tyge (samt hans embedsbroder biskoppen i Slesvig) er stilet til den danske kong Erik (Glipping). Atter drejer det sig om, at abbeden i Løgum Kloster har købt en fjerdedel af Alslev Otting, men at arvingerne efter sælgerens død ikke vil godkende handelen. En ejendommelig ting er dog, at den mand, som har solgt skovparten til klosteret i dette tilfælde hedder Marte Lille, medens han som sagt $\mathrm{i}$ første brev hed Mark Rød. Hvad „fornavnet« angår kan dette skyldes en skrive- eller læsefejl, hvorved Mark er blevet til Marte, (eller omvendt). At tilnavnet er forskelligt kan måske forklares ved, at manden har haft mere end et kendingsnavn.

\section{Klostrets kamp for sine rettigheder}

De arkivalier, som omtaler Draved i middelalderen er få, spredte og tilfaldige. Efter de nævnte breve fra 1200-tallet følger en lang tavshed. Således er 1300-årene fuldkomment mørke, sikkert ikke fordi der intet er sket i denne periode, men snarest på grund af, at de skriftlige meddelelser, som evt. har foreligget, er gået til grunde.

Af de tre breve fra 1200-tallet ses, at klosteret til tider måtte kæmpe hårdt for sine "rettigheder" $\mathrm{i}$ skoven, $\mathrm{og}$ at problemet ikke er blevet mindre $\mathrm{i}$ de følgende århundreder, viser flere tingbreve fra 1400-årene, hvori der igen træffes afgørelse om ejendomsretten til Draved skov. Ikke alle var enige med munkene i, hvem skoven tilhørte. Det var normalt klosteret, der gik af med sejren i disse stridigheder, og det skyldtes bl.a. dets dygtige ledere. En af dem, der især rager op, er abbed Claus, som øjensynlig er klosterets abbed i mere end et halvt hundrede år: vistnok fra lidt før midten af 1400-tallet til hen imod århundredets slutning.

Denne handlekraftige mand kæmper bravt for klosterets "rettigheder «. I et tingbrev fra 1440 er det endnu lidt uklart, hvem der egentlig kan tænkes at anfægte disse rettigheder, det hedder blot, at »hæderlig mand broder Claus, abbed i Løgum Kloster, lydelig æskede og bad om det var menige herred vitterligt, hvem der har haft skovhjemmel i Draved, Moskær og andre kær, som de har hugget $\mathrm{i}$ indtil denne tid, og æskede derpå et uvildigt tingsvidne, hvilket vidne, som han æskede, fik og fremlagde af otte beskedne dannemænd, som var... «

Senere (hen imod 1500) bliver det mere klart, at det især er Eggert Gjordsen, herremanden på Solvig i Hostrup sogn, som også har fingrene ude efter Draved skov. Dog ender det med en afgørende sejr for abbed Claus, og i et tingbrev fra 1492 læser man, at "når fornævnte Eggert ville have kærhugst $i$ 
For få år siden kendte de gamle på egnen betegnelsen " $E$ Skovdige “, 9 de vidste at fortælle langs hvilke hegn, marskel o.s.v. "Æ Skovdige“ havde gået, selvom det forlængst var forsvundet. Dette dige har som regel ligget et stykke uden for den nuværende skov. Det ses tydeligt $i$ heden nord for skoven (vest for den asfalterede vej til Løgumkloster). Endvidere fremtræder det meget klart lige vest for skoven, hvor det undtagelsesvis ligger i skovkanten, men ellers er det væk de fleste steder. Det er nærliggende at betragte " $Æ$ Skovdige« som en begrænsning af den tidligere skov, men om det virkeligt er identisk med Draved dige bliver blot gætteværk. Hvornår og af hvem Draved dige er bygget, kan man også kun gisne om. Måske har munkene ladet det opføre som et led i bestræbelserne for at sikre deres ejendomsret til skoven, og det må således være sket før 1481, hvor diget første gang omtales.

Som tidligere nævnt led Eggert Gjordsen på Solvig ved retskendelsen af 1492 et ydmygende nederlag i striden med Løgum Kloster, og man skulle derfor tro, at han nu havde tabt modet. At dette ikke er tilfældet fremgår af et tingbrev, hvis datering er noget usikker, men som synes at være skrevet efter abbed Claus's død (i 1490'erne?). Måske er denne sørgelige begivenhed netop grunden til, at Solvigmanden prøver endnu et fremstød i den tro, at han lettere vil kunne få ret over for klosterets nye abbed. Det bliver dog også denne gang en skuffelse, idet den dom, som falder, bliver til gunst for Løgum Kloster.

\section{Draved - bonder i 1500-tallet}

Fra årene 1500 og 1519 foreligger breve, som for alvor slår fast, at Draved skov tilhører Løgum Kloster, så meget mere som den ligger i Løgum sogn. ${ }^{10}$ Dette sidste er især understreget i skrivelsen fra 1519, hvori det fortælles, at tre navngivne mænd: Nis Droffuit, Oluf Plade og Per Drowidt, alle født $\mathrm{i}$ Draved, også alle er blevet døbt i Løgum kirke. De to førstnævnte er desuden begravet henholdsvis på Kloster kirkegård og Løgum kirkegård. Desuden er den mand, som nu (1519) bor i Draved, Jes Kalissen, ægteviet i Løgum kirke. Også andre af 1500-tallets Draved-boere kendes, således Jep Jensen, der i 1539 optræder som vidne $i$ en retssag. Og i en skatteliste fra 1548 nævnes en "Rasmis i Draufwydt «, der skal betale 3 skilling i frøkenskat. " Bortset fra navnene er det ikke meget vi kender til disse mennesker. Man må dog nok antage, at det har været bønder, som har fristet tilværelsen på én eller flere rydninger i skoven. Der kan her mindes om, at navnet "Hussted " forekommer på det gamle skovkort fra 1780 (se fig. 2), og at der i nærheden er fundet spor af højryggede agre. Selvom der ikke lå noget hus her, da skoven blev opmålt i 1780, kan man med rimelighed antage, at der tidligere har ligget et hus eller en gård på lysningen. Senere slår mennesker sig igen ned på eller 


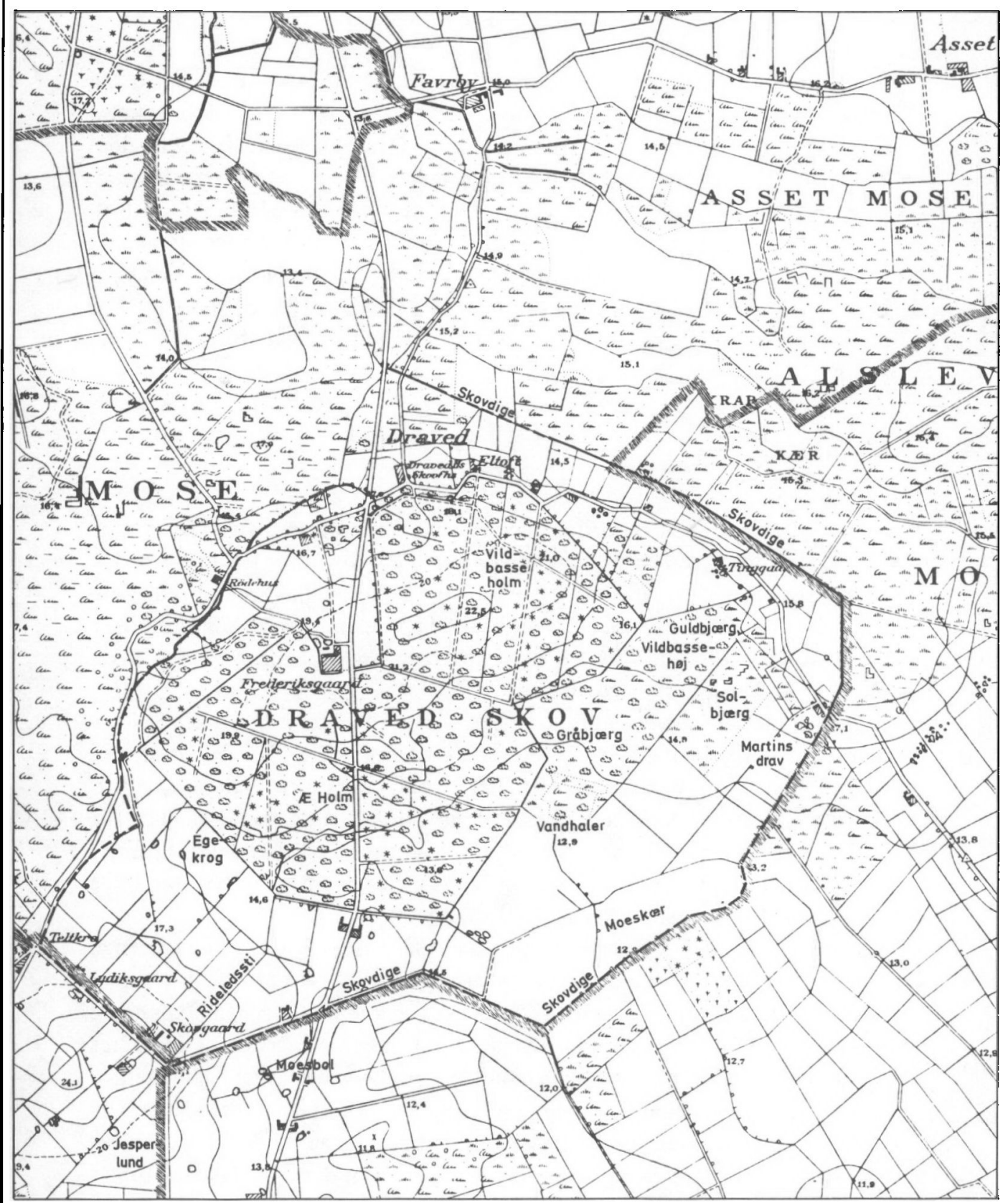

Fig. 3. Udsnit af Målebordsblad l:20.000. gengivet i formindsket målestok. Reproduceret med Geodatisk Instituts tilladelse (A272/80). Copyright. De vilskrevne navne er meddelt af Jan Marcussen, Skovgård og Christian Bendorf. Øster Hojst. Fuldt optrukken linje betegner de steder, hvor der endnu ses rester af skovdiget, punkteret linje de steder, hvor diget nu er forsvundet. 
ved Hussted, idet den nuværende Frederiksgård i 1780-erne opføres i nærheden af stedet.

I 1536 kom reformationen til Danmark, og dermed indledtes en helt ny epoke. Der blev gjort ende på kirkens verdslige magt, og dens jordegods kom i reglen i statsmagtens eller adelens besiddelse. En stor del af klostrene fik dog endnu en tid lov til at bevare de ydre rammer. Dette gælder også Løgum Kloster, hvis privilegier stadfæstes i to tingbreve fra 1539. Heri får klostret slået fast, hvor herredsskellet rettelig går, så der ikke hersker nogen tvivl om, at Draved hører med til Lø herred og dermed til Løgum Klosters domæne. Dog blev klostergodset med den sidste abbed, Morten Iversens død i 1548 i realiteten et amt (Løgumkloster amt) hørende ind under hertug Hans den aldre i Haderslev.

\section{Ulvejagter}

\section{Ulveplagen}

"Tyv skal hæenges i galge med gennemstukne sener, og en ulv ved hans side, for at den onde mand og det arge udyr kunne få en og samme straf “. Således lyder iflg. Saxo en af den berømmelige sagnkonge Frode Fredegods forordninger (Olriks oversættelse). - Denne ældgamle skik, som holdtes i hævd indtil midten af 1700 -tallet og muligvis endnu længere, viser, hvor frygtede og hadede disse rovdyr var.

Den skade, som ulvene anrettede på de løsgående kreaturer i skove og på marker, var til tider meget omfattende og følelig. De blev derfor stærkt efterstræbte, og $\mathrm{i}$ begyndelsen af 1600-tallet synes deres antal at være betydeligt formindsket. Men under dette århundredes krige, bl.a. under svenskekrigen 1657-60, forøgedes ulvebestanden igen. Folk havde da andet at tænke på end at jage vilddyrene, og det fortælles, at store flokke fulgte efter de fremmede hære, som da drog ind $i$ landet.

I de følgende 100 år var ulveplagen da også særlig slem, navnlig i strenge vintre, hvor dyrene kunne blive så dristige, at de vovede sig helt ind $i$ landsbyerne. Derfor blev der i 1677 udnævnt en kgl. ulvejæger for Jylland og Slesvig, og i 1680'erne udsendte ulvejægeren Johann Tänzer en rigt illustreret jagthåndbog, et værk, som bl.a. behandler ulvejagt og beskriver de forskellige måder, hvorpå ulve kan jages og fanges (fig. 4). Regeringen prøvede også at opmuntre til rovdyrenes udryddelse ved at udlove præmier for dræbte ulve. Der blev udsat en dusør på 4 rigsdaler for et voksent dyr og 1 rigsdaler for en unge. ${ }^{12}$ De nedlagte ulve blev bragt til tinge, så øvrigheden kunne se dem, og blev derpå hængt op i galgen eller i et højt træ. Jægeren havde ret til ikke blot at indkassere dusøren, men også at beholde bælgen. 


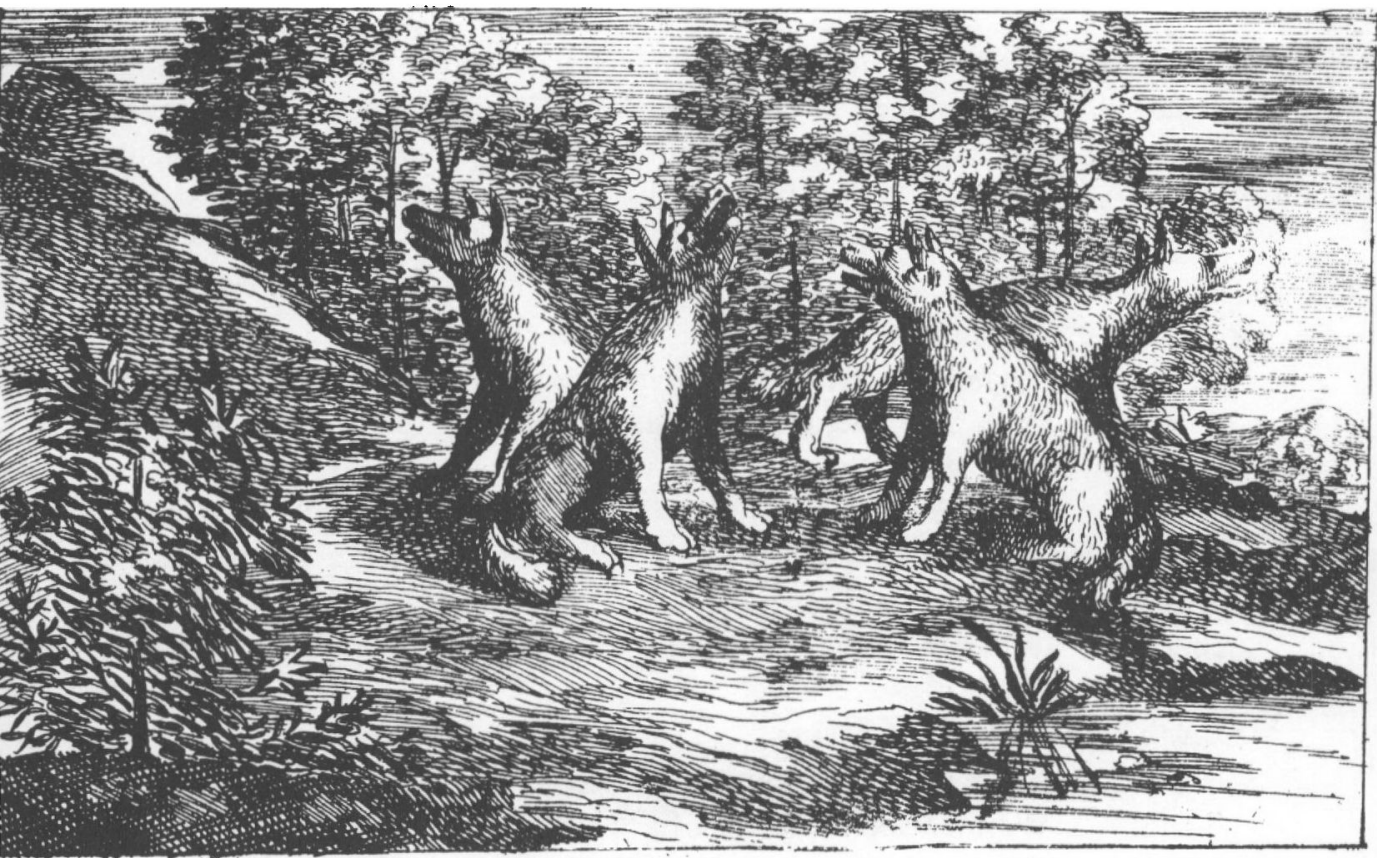

Fig. 4. Illustration fra Johann Tänzers jagthåndbog fra 1682.

Ulvene kunne nedlægges på flere måder. Mange blev simpelthen skudt af den enkelte mand, som færdedes i skov eller mose, men også fælder af forskellig slags fandt anvendelse. En af dem var "ulvegraven«, d.v.s. faldgruben. Den var ca. $3 \times 3 \mathrm{~m}$ og af lignende dybde, og undertiden var der anbragt en spids pæl i midten. Graven var overdækket af grene og kviste, og tit blev der brugt lokkemad for at få ulvene til at gå ud på det skrøbelige dække. Men der blev også foranstaltet mere omfattende klapjagter med stort opbud af mandskab, evt. fra flere amter.

Disse klapjagter var som regel meget effektive, men forstmændene var ikke glade for dem, idet det gik hårdt ud over skovens øvrige vildt. I stedet for at sætte de helt store fællesjagter i scene, nøjedes man da i vise tilfælde med at »berende ulven « d.v.s., at man på forhånd fandt ud af, hvor ulvene havde deres tilholdssteder. Derefter blev der tilsagt mandskab fra nogle nærliggende landsbyer, og den tykning eller sump, hvor ulvene holdt til, blev omkredset, mens skytter blev udsat på strategisk vigtige punkter. Derpå blev dyrene drevet frem og så vidt muligt nedlagt. - Altså dog en slags klapjagt, men i mindre format.

Men yndede skovens folk ikke de store ulveklapjagter, så var bønderne, der 
fungerede som klappere, heller ikke altid lige begejstrede. Det var, ialt fald i kongeriget, en regel, at enhver ejendom med hartkorn - selv om det også var af de små - skulle stille »en jagtbar karl med behørige våben«. Tit foregik jagten midt $\mathrm{i}$ den kolde årstid og indtil flere dagsrejser fra hjemegnen. Mens jagten fandt sted, var klapperne under ledelse af sognefogederne, som skulle føre opsyn med dem "fra dagens anbrækning til dens undergang “. Dette lederskab foregik, såvidt vides, $i$ al fredsommelighed, men ofte blev der klaget over, at den behandling, klapperne fik fra skovbetjentenes side, var både hård og vilkårlig. Engang efter en sådan jagt indsendte bønderne på Trøjborg gods da også en klage over »det uanstændige tractemente«, som de havde været udsat for.

Dog var bønderne mere end villige, når det drejede sig om fællesjagter $\mathrm{i}$ det hjemlige herred eller tilgrænsende egne, så de evt. kunne få ram på nogle af de ulve, som overfaldt deres egne kreaturer, og i sådanne tilfælde kunne det endog ske, at de selv ansøgte amtmanden om tilladelse til at holde klapjagt.

\section{Ulve i Draved skov i 1750 'erne}

Naturligvis var de mest vildsomme dele af landet og de egne, som var tyndest befolket, særlig hjemsøgt af ulvene. Et af disse områder var egnen syd for Løgumkloster, hvor Draved skov lå omgivet af vidtstrakte moser og hedestrækninger. Hvad der særlig gjorde det vanskeligt at komme ulvene til livs her, var, at Løgumkloster og Tønder amter dengang grænsede op til hinanden umiddelbart syd for skoven. Og bønderne fra det ene amt kunne ik ke uden videre føre en klapjagt ind på det område, som hørte til det andet. I så fald måtte der mange skriverier til og tilladelse fra amtmand, jægermester osv.

Talrige dokumenter, som omhandler større og mindre jagter i og omkring Draved skov, opbevares $i$ arkiverne. De synes at vise, at ulveplagen på denne egn var særlig slem $i$ to perioder af 1700-tallet: i midten af 50-erne og begyndelsen af 70-erne. Der blev i disse perioder afholdt mange ulvejagter, og af skrivelserne fremgår, at dramaets hovedpersoner var: amtmand Lucas, jægermester Gruttschreiber og skovrider (Hegereiter) Eschelsen Bagge.

I efteråret 1752 indsender indbyggerne $\mathrm{i}$ Tønder amt en ansøgning om at måtte afholde ulvejagt i Draved skov. Denne jagt, der uden tvivl er ment som en virkelig klapjagt, bliver dog ikke udført i sit fulde omfang, idet skovrideren erklærer, at noget sådant vil være til stor skade for skovens rådyrbestand. Imidlertid giver jægermesteren, som gerne vil være imødekommende, ordre til, at "ulven skal berendes".

Om resultatet heraf blev stort eller lille, vides ikke. Snarest det sidste, for to år senere, i september 1754, modtager amtmanden påny en ansøgning fra 
befolkningen i Tønder amts nordligste herreder. Skrivelsen, som er affattet på tysk, er af følgende indhold: Man har i nogle år lagt mærke til, at ulvenes antal - ikke blot i Tønder amt, men også i tilgrænsende egne - i den grad forøges, at man nu næsten daglig mærker, hvordan snart et, snart et andet af kreaturerne på marken bliver skadet og revet ihjel af disse rovdyr. - Derfor anmodes "den nådige, højtbefalende Herr Amtmand" om tilladelse til en klapjagt i Draved skov og mose. ${ }^{13}$ Ydermere vedlægges en skriftlig erklæring fra moseforpagteren, hvori denne attesterer ulvenes store antal og særlige tilhold på egnen.

Men også i denne omgang prøver skovrideren at stikke en kæp i hjulet. Han søger at bagatellisere sagen ved over for jægermesteren at hævde, at der nu bare er to, ja måske endda kun én ulv tilbage i Draved. Og selv om der er gjort en del skade på bøndernes kvæg, så kan han dog ikke anbefale en ulvejagt for ét omstrejfende dyrs skyld.

$\mathrm{Nu}$ er jægermesteren åbenbart $\mathrm{i}$ en vis knibe, men for at skifte sol og vind lige, beslutter han sig til endnu engang at "lade ulven berende“. Bagefter må skovrideren rigtignok indberette, at nogle ulve er undsluppet ved jagten, og at de fortsætter med at angribe husdyrene på marken. Derfor ansøges der om, at de yderligere må jages.

Bønderne opgiver altså ikke ævret, og i august næste år (1755) indsender de atter ansøgning om en almindelig klapjagt i Draved skov. - Og deres udholdenhed belønnes, idet der nu, mærkeligt nok, ikke synes at være betænkeligheder fra de højere myndigheders side. Jagten bliver berammet til efter høst, og den finder sted mandag den 7. okt. Men hvordan det nu end forholder sig, så bliver resultatet magert, idet kun to ulve bliver nedlagt, men en del undslipper. Det er derfor påkrævet med en ny jagt, og jægermesteren modtager også en anmodning derom, men hvad det bliver til, vides ikke. Endnu i september 1756 høres der stadig om ulve på egnen.

Det er altså klart, at rovdyrene ikke blev udryddet ved 50-ernes ulvejagter, men stærkt formindsket $i$ tal er de dog nok blevet, evt. ved andre jagter end dem, vi kender til. Således fortæller folkemindeforskeren Axel Olrik om en gammel mand, født i 1735. Han gik engang i sin ungdom (i 1750'erne?) over Ellum banker, vest for Logumkloster, efter at der nylig var holdt klapjagt $i$ Draved skov, og han så da, at der i en oprejst galge hang ikke mindre end 14 ulve. ${ }^{14}$ Denne skik at hænge de dræbte ulve op $i$ en galge ligesom andre forbrydere har vistnok været almindelig i Sønderjylland, i alt fald omtales den også af en polak, som engang i 1600-tallet besøgte Slesvig. ${ }^{15}$

Ulveplage igen ca. 1770

Måske opnåede man, at ulvene til en vis grad er blevet fordrevet fra egnen. 
Det er i hvert fald karakteristisk, at der herefter $\mathrm{i}$ en årrække er meget stille om ulvene i Draved, men helt forsvundet er de ikke, og i 1770 hører man, at de igen har forøvet skade $\mathrm{i}$ Tønder amt og revet en del får og kalve ihjel. Bønderne søger da, ligesom tidligere, om at der må blive holdt en klapjagt fælles for de to amter. Dette ønske bliver imødekommet, og jagten afholdes torsdag den 4. okt. 1770. Om udbyttet foreligger ingen meddelelser, men det er sandsynligt, at nogle af ulvene er undsluppet, eftersom en ny ulvejagt finder sted allerede den 4. febr. næste år (1771). Resultatet af denne blev dog det dårligst tænkelige, idet ikke en eneste ulv blev set. Amtmanden skriver derfor, at han retfærdigvis må betvivle, at rovdyrene har deres tilholdssteder alene i Draved skov og moser, så meget mere som der i den senere tid kun en enkelt gang er set ulve i Draved. Den høje embedsmand mener derfor ikke, at det kan lønne sig at afholde yderligere ulvejagter dér på egnen.

Således forsvandt da ulvene fra Draved, men endnu i vore dage kender eller kendte de gamle fra den sydlige del af skoven navnet »ulvevolden«. Hvilken forbindelse den har haft med disse rovdyr har dog ikke kunnet opklares. Der kan dog i denne forbindelse nævnes en beretning om, at der i gamle dage var opført jordvolde til beskyttelse mod ulvene omkring visse landsbyer mellem Løgumkloster og Ribe. ${ }^{15}$ Endvidere fortalte en aldre mand, som var barnefødt på egnen, at man endnu $i$ hans unge dage kunne se spor af mulvegrave $i$ den sydøstlige del af skoven (Chr. Bendorff, $\varnothing$. Højst).

Også andre steder i landsdelen huserede ulvene slemt. Således er der beretning om, at de ved midten af 1700-tallet bl.a. holdt til i Frøslev Sand, hvor der også var gode skjulesteder. - Hvornår de sidste sønderjyske ulve er blevet udryddet vides ikke med sikkerhed. Rimeligvis er det sket i slutningen af 1700-tallet.

\section{Misligheder i Draved skov}

En to gange hangt forbryder

Beretninger om to gange henrettede forbrydere kendes fra flere steder, og også Draveds historie kan byde på en sådan makaber episode.

Den Hostrup præst, Peder Rigelsen, skriver i 1598 således:

"Ludde Janssen, boende i Blesborg og født i Kraulund, der i sine unge år har slået sin faders arm over og nu i disse år havde stjålet meget træ fra Dravit ved Løgumkloster og antændt og afbrændt det fyrstelige vogterhus eller vagten ved nævnte skov (Dravit), blev hængt op, første gang en mandag, var den 19. juni, thi medens skarpretteren fik sine to fingre klemt mellem galgestolpen og strikken, lod han tyven hænge så længe til han troede, at misdæderen måtte være død. Og ville skarpretteren have sine fingre fri, måtte 
han skære den strik over, der snørede misdæderens hals sammen, og da han gjorde det, greb han fejl, fordi han var drukken, og fik ikke jern-(ringen) sat på krogen, hvorved misdæderen faldt ned og kom (på benene igen)....

Torsdag derefter, den 22. juni, blev han hængt. Galgen var rejst på samme sted, hvor misdæderen havde afbrændt den fyrstelige vagt «. ${ }^{16}$

Selvom det vel hørte til sjældenhederne, kunne sådanne drastiske begivenheder finde sted i Draved for omtrent 400 år siden, og man må tro, at de - efter deres hensigt - har virket til skræk og advarsel. I de følgende mange år høres rent faktisk meget lidt om forseelser i skoven; vel ikke fordi befolkningen $i$ denne periode var særlig lovlydig. I så henseende har den sikkert hverken været værre eller bedre end til alle andre tider; og det at tage lidt træ i skoven til at varme sig ved eller en smule ris til en riskost blev ikke anset for nogen egentlig forbrydelse. Man vidste vel, at skoven, og hvad den indeholdt, tilhørte hertugen (eller kongen), men han sad jo så langt væk og kunne have svært ved at håndhæve sin ret. Ganske vist var der ansat en skovfoged med pligt til at passe på tyve af enhver art. Men skovfogederne i 16-og 1700-tallet var tilsyneladende ikke særlig ivrige efter at rapportere uregelmæssigheder, enten det nu skyldtes almindeligt sløseri, eller at de gerne ville stå sig godt med den stedlige befolkning.

\section{Forbudt grasning $i$ skoven}

I midten af 1600-tallet hører man imidlertid, at bønderne lader deres dyr græsse i Draved skov, hvilket også var strengt forbudt.

Den 9. sept. 1642 skrev hertug Frederik af Gottorp, som da var skovens ejer, til amtmanden i Løgumkloster desangående. Det er et noget irriteret brev, selv om det er holdt i yderst høflige vendinger. Åbenbart har hertugen tidligere givet amtmanden besked om at hegne Draved skov, så bøndernes kvæg ikke kunne komme derind, men nu hører han, at der alligevel ikke er sket noget, så han giver endnu engang amtmanden befaling om, at han skal sætte bønderne til at lave sådan et hegn, eller også skal han meddele dem, at de har at holde deres husdyr fra at græsse i skoven. Sker det alligevel, at der træffes kreaturer inden for skovens enemærker, skal de føres til Løgumkloster, og ejeren må da betale en bøde for hvert dyr. ${ }^{17}$

Om disse skrappe forholdsregler virkede, vides ikke. Sandsynligvis er man efter nogen tids forløb, atter faldet tilbage til den gamle slendrian. Herpå tyder den omstændighed, at jordebogen $1704^{18}$ omtaler Draved skov som givende græsning for 100 stk. ungkreaturer foruden heste. Desuden findes på det gamle skovkort (fig. 2) fra 1780 navnet "Kresti « brugt om den nordlige del af skoven, og da »kræu her formentlig betyder husdyr, har man grund til at formode, at det ikke var ualmindeligt at finde »kra i skoven. Endvidere 
træffer skovfogeden i forsommeren 1809 to køer i skoven. De blev vogtet af Nicolai "Treskomann «, Frederiksgårds parcellist, et eksempel på, at i hvert fald fattigfolk forstod at skaffe sig billig skovgræsning til deres kreaturer. ${ }^{19}$

\section{Tyveri af tra $i$ 1800-tallet}

Fra første halvdel af 1800-tallet foreligger en hel række rapporter om skovforseelser, udfærdiget af skovfogeden og som regel stilet til husfogederiet i Løgumkloster. De kaldes gerne "Forst- og Jagtbrøderapporter", men der er $\mathrm{i}$ almindelighed udelukkende tale om tyveri af træ. Selvfølgelig har krybskytteri ikke været så sjælden en foreteelse, som det ser ud til, især ikke i en så afsides egn. Men sikkert har skovfogeden følt, at han over for sine overordnede skulle vise sig som den samvittighedsfulde embedsmand ved at indsende så mange rapporter som muligt. Imidlertid var jagten på de svært bevæbnede krybskytter alt for farlig; den kunne komme til at koste både liv og førlighed. Så var de sølle trætyve både nemmere og mere ufarlige at have med at gøre, og der bliver gjort meget ud af den slags tilfælde, selv om det ofte synes at dreje sig om rene bagateller.

Gennem rapporterne får man imidlertid oplysning om, hvilke træarter, der har været mest eftertragtet og i visse tilfælde hvad de har været brugt til. Eg og bøg, birk og el er hyppigt blevet taget fra skoven, men også poppel, pil, lind og røn går det ud over.

En del af det stjålne træ er naturligvis blevet brugt som brændsel, selv om det ikke direkte nævnes. Pilevidjerne blev anvendt til kurvefletning, og birkeris er antagelig brugt til riskoste. De blev ofte stjålet af karlene på de omliggende gårde, og da der som regel er tale om større mængder ris, har de sikkert ikke blot lavet koste til eget brug, men ved salg til bekendte har de også tjent en ekstraskilling. Endvidere er der tale om fire unge egetræer forarbejdet til plejle, som blev fundet hos Chresten Rasmussen på Vennemose Mark, og i marts 1828 fandt skovfogeden i Draved hos Cornelius samme sted nogle vognkæppe lavet af frisk bøgetræ, som han er overbevist om stammer fra skoven.

I efteråret 1809 har nogle karle fra gårde i nærheden skåret en større portion birkeris $\mathrm{i}$ skoven. De bliver pågrebet og kommer ikke til at dø $\mathrm{i}$ synden. Allerede året før er der tale om et parti brænde, som er fældet i den statsejede del af skoven og derefter ført til den part, som hører til Frederiksgård. Her har det ligget en tid, til tyvene i ro og mag kunne køre det bort.

Men et af de større kup gør skovfogeden dog, da han hos snedker Hans Jensen $i$ Vennemose finder et antal træer, som han mener, stammer fra 
Draved. Ganske vist er det kun småtræer, men små eller store, det drejer sig i alle tilfælde om: 9 ege, 17 birke, 3 elletræer, 15 rønne, 4 popler og 12 linde.

Ejendommeligt er det at lægge mærke til, at tyverierne i skoven ofte bliver begået på en søn- eller helligdag eller natten efter en sådan! Måske ud fra den betragtning, at skovfogeden da var mindre årvågen end ellers (hvad iøvrigt synes at være en fejlslutning) eller også fordi man på helligdagene havde god tid til den slags små »ekstraarbejder«. Gang på gang hedder det i rapporterne, at et tyveri blev begået på den og den dato "als am Sonntage«. Endvidere bliver der stjålet træ anden pinsedag 1826, i påsken 1838 og ligeså påskedag 1843. Og i august 1830 var tyven ude på selve Bartholomæus' markeds dag, d.v.s. dagen for det nuværende Kloster marked (navngivet efter St. Bartholomæus dag, den 24. august).

Trætyvene blev gerne straffet med bøder, som dog undertiden kunne arbejdes af. Således må Nis Christensen Schmidt (søn fra Teltkroen vest for Draved) i foråret 1824 arbejde $1 \frac{1}{2}$ dag i skoven, fordi han er mistænkt for at have tilvendt sig nogle birkeris fra Draved, og i marts 1828 har han igen været på gale veje, idet der på kroens høloft findes seks unge birketræer, som han straks tilstår at have stjålet i Draved. I 1842 må tre navngivne mænd ligeledes arbejde i skoven som straf for begåede tyverier.

\section{En nidkar skovfoged}

En særlig streng tid for tyvene i Draved er årene 1824-1843. Da er nemlig skovfoged Warner ansat $i$ embedet, og han er en meget nidkær mand. Således er to tjenestekarle søndag den 13. marts 1825 atter i færd med at stjæle birkeris samt en portion træ til tagspåner. Skovfogeden, der anholder dem, påstår, at det er tyvekoster fra Statsskoven, medens de på den anden side selv hævder, at det stammer fra Frederiksgårds skovpart ("Peter Andresens såkaldte hale«). ${ }^{20}$ Der hjælper dog ingen udenomssnak. I februar et par år senere er to mænd fra Løgumkloster i færd med at hente noget brænde, som de har købt i skoven. Da skovfogeden møder dem på vejen mellem Draved og Løgumkloster, forekommer læsset ham vel stort, og det viser sig da også, at der på vognen ligger flere træer, som de ikke er kommet retmæssigt til. Det drejer sig om een birk og et par unge bøge, som har stået tæt ved de lovligt erhvervede træer, og som de derfor er kommet til at tage med.

Især i sommeren 1830 går det hårdt ud over træbestanden. I juli og august opdager skovfogeden, at adskillige træer er fældet og fjernet fra skoven. Ialt er der stjålet 57 mindre træer: 19 linde, 14 birke, 13 rønne, 5 popler, 3 ege, 2 elletræer og 1 pil.

En anden gang er der taget 21 linde og tre rønnetræer. - I det hele taget synes der mellem det stjålne at være påfaldende mange birke og linde, de $10^{*}$ 
første vel på grund af deres formodede anvendelse til koste, men hvorfor lindene? Havde man brug for basten eller blev de foretrukket, fordi de med deres bløde ved var lette at fælde? Man bemærker også, at der i reglen kun stjæles småtræer. Dog er det en enkelt gang gået ud over større eksemplarer: 1 lind på 11 tommer, 3 ege på 10-11 tommer eller en bøg på 12 tommer i diameter.

Den 13. jan. 1826 afholdtes der klapjagt i Draved skov. Til stede er blandt andet Chresten Brodersen fra Søegård med sin flintbøsse. Under jagten fjernede han sig og skød (åbenbart for egen regning) en hare, hvis spor sås $\mathrm{i}$ den nyfaldne sne. Denne forseelse bliver naturligvis indberettet til husfogederiet.

I 1843 ophører skovfoged Warners embedstid, men i de følgende 7-8 år, hvor han efterfølges af skiftende kolleger, berettes stadig om talrige tilfælde af tyverier. En af de sidste lovovertrædelser, der høres om i Draved, er fra maj 1851. Af skrivelsen fremgår, at skovopsynsmand Erhardt, "der fungerer som skovfoged i Drawittskov« har fanget gerningsmændene til et tidligere omtalt trætyveri: en bøg, 12 tommer i diameter, som er afsavet, og hvoraf der er udskåret tre stammeenheder á tre alens længde. Disse er nedgravet i skoven til senere afhentning. Gerningsmændene er to skovarbejdere fra Høgslund, som begge har tilstået "Gjerningerne « for skovopsynsmanden.

Men om efteråret samme år besættes skovfogedembedet i Draved med en ny mand. Det er Peter Andresen, og dermed oprinder der en ny tid for skoven. Den ny skovfoged er nemlig levende interesseret i skovens ve og vel og med på alt nyt. Der bliver tiltrukket ungplanter i planteskoler, foretaget nyplantninger, især med nåletræ, og der sættes grøftearbejder igang. Alt dette praktiseres både under dansk og (efter 1864) tysk overhøjhed. Derimod bryder skovfoged Andresen sig ikke stort om, hvorvidt folk for egen regning tager en smule træ i skoven, og at skrive rapporter om den slags bagateller, kunne $i$ hvert fald ikke falde ham ind.

\section{Om skovbrande i 1850 -erne}

At oldtidsbønderne af og til har afbrændt dele af skoven for at skaffe sig arealer til græsning og dyrkning, derom vidner pollendiagrammer og trækullag. Men ved denne forsætlige afbrænding har ilden været under stadig kontrol og har ikke fået lov at brede sig mere, end på forhånd var beregnet. Anderledes med de mere tilfældige brande, som kunne opstå ved menneskers uforsigtighed eller ved lynnedslag.

Fra 1850'erne har vi beretning om flere sådanne brande, mere eller mindre omfattende. - Naturligvis har der også været skovbrande både før og siden, 
vi har blot ikke kendskab dertil, men da det formentlig er foregået på nogenlunde samme måde hver gang, kan det være oplysende at høre lidt om skovbrandene ved midten af 1800 -tallet.

Den 25 . maj $1853 \mathrm{kl}$. 10 om formiddagen udbrød der ildløs i Draved skov. Ilden forårsagedes af en hedebrand syd for skoven og bredte sig ind $\mathrm{i}$ den sydlige del af denne. Den daværende skovfoged P. Andresen underretter samme dag pr. brev Linnet skovdistrikt om branden. Distriktet modtager meddelelsen den 26 . maj og sender en rapport til overførsteren den 27 , altså en temmelig langsommelig affære.

Samme dag, som branden udbrød, havde skovfoged Andresen endvidere mundtlig meddelt det skete til "Det Kgl. Birkefogderi« i Løgumkloster, og herfra går meddelelsen videre til husfogderiet samme sted hvorefter dette tilsiger slukningsmandskab (den 27. maj). Bl.a. får Løjtved besked om at stille » 20 mand med de behørige slukningsredskaber «. Mandskabet skal stille ved skovfogedboligen kl. 8 om morgenen.

Men allerede forinden har man ved frivilliges hjælp fået bugt med ilden. Andresen skriver den 27. maj til amtsforvalteren, at da ilden i skoven nu må anses for slukket, er det ufornødent at skaffe mere mandskab. Imidlertid har birkefogderiet $\mathrm{i}$ den almindelige forvirring glemt at sende meddelelse om branden til "Amtshuset " i Tønder, hvorfor det et par dage efter modtager et noget syrligt brev fra amtshuset, hvori dette beklager sig over ikke at have fået skriftlig meddelelse om begivenheden. Ganske vist har man underhånden fået besked om branden, og har sendt en gendarm til skoven for at orientere sig. Han beretter, at ca. en trediedel af skoven tildels er ødelagt af ilden. Underskoven er brændt, og kvas og udgåede stammer ligeledes. Derved er også de friske stammer blevet mere eller mindre forkullet og beskadigede, så det er et spørgsmål, om de kan blive til noget mere.

Brevet har som sagt en undertone af irritation, hvorfor birkefogderiet skynder sig at indsende en rapport. Denne er meget fyldig, og giver et godt billede af de dramatiske tildragelser. Det fortælles, hvor og hvornår branden opstod, og hvordan ilden bredte sig. En mand, der blev sendt til skoven beretter, at det ved hans ankomst brændte adskillige steder, men ved de tililende menneskers hjælp lykkedes det at begrænse ilden, så at der henad aften ingen fare var for, at den yderligere skulle brede sig. Da Frederiksgård, som ligger tæt ved skoven, en tid var truet, blev en sprøjte fra byen kørt dertil, men der skete heldigvis ingen skade hverken med mennesker, bygninger, sæd eller kreaturer.

Da branden, som før nævnt, var slukket den 27, maj, er et areal på ca. 150 tdr. land raseret, og mange træer er beskadiget, men hvor stor skade, der egentlig er sket, kan ikke overses. 
Men hvordan er ilden opstået? Det er det store spørgsmål, men da det ligger klart, at branden er begyndt i den Frederiksgård tilhørende hede, så samler mistanken sig efterhånden om gårdens hyrdedreng, en 13-14-års knægt ved navn Jacob. Der bliver holdt forhør over ham, men da han vedblivende nægter, kommer der ikke mere ud af sagen.

Allerede i april næste år er der igen ild i Draved skov. - Hvilken del af skoven det denne gang gik ud over, vides dog ikke, da der kun foreligger meget sparsomme oplysninger. Det drejer sig om et enkelt brev fra skovfoged Andresen, hvor han beder amtsforvalteren om noget mandskab til at våge over ilden, at den ikke skal gribe videre om sig.

Endelig kan det ses, at en skovbrand har fundet sted den 28.-29. maj 1859. Andresen indsender nemlig en regning for nogle folk, som han har haft til hjælp som opsynsmænd ved slukningsarbejdet. Da dette har stået på i mindst tolv dage, kan man gå ud fra, at branden har været af ikke helt ubetydeligt omfang. Ved denne lejlighed har det åbenbart knebet lidt med slukningsmateriellet, for den 30. juli skriver Andresen til overførsteren og anmoder om, at der må anskaffes nogle manglende brandrekvisitter til skoven. Overførsterens svar indløber først i september, med ordre om anskaffelse af een læderbrandspand til Draved skov!

\section{Veje, grøfter og gamle diger \\ Gravning af grefter}

Draved skovs beliggenhed i fugtige og ufremkommelige omgivelser har især i gammel tid været meget generende. Egentlige anlagte veje har der dengang næppe været, men færdselen er vel foregået ad de mere højtliggende rygge, hvor der efterhånden er opstået en samling dybe hjulspor. Gravede grøfter har der sikkert heller ikke været, men vandets afledning er foregået ad de naturlige lavninger, hvorigennem der er sket en meget langsom afstrømning.

Hvornår man er begyndt at grave grøfter i Draved, ved vi ikke. På det gamle skovkort af 1780 (ja, endnu på et kort fra 1801) er hverken angivet grøfter eller veje, men det behøver ikke at betyde, at der slet ingen har været; de har blot været små og ubetydelige og har ikke haft opmålerens interesse. Det er imidlertid sandsynligt, at de første større grøfter i Draved skov er gravet i begyndelsen af 1800-tallet. Således findes en lille annonce eller opslag fra maj 1837 undertegnet af den daværende skovfoged Warner, hvor han på grund af, at der skal graves en del "grøvter" i Draved efterlyser "arbejdsduelige og arbejdslystne subjecter" til at tage arbejdet i akkord.

Det er muligt, at ingen har meldt sig, for allerede den 18. aug. samme år får man at vide gennem et brev til skovfogeden, at dræningsarbejdet er 
overdraget ejeren af Frederiksgård, Hans Hündig Petersen. Han har fået strenge instrukser om, hvordan han skal forholde sig, og han kan tage så mange folk til hjælp, som han har brug for.

Efter at Warner 1843 var gået af som skovfoged i Draved, og efter at embedet havde været kortvarigt besat med skiftende mennesker, kommer i 1851 så skovfoged Andresen til. En del skrivelser - mest regninger, viser, at der $i$ hans tid udførtes både en del vej- og grøftearbejder. Således ses af en regning over "uforusete Udgiwtsposter" at en af skovvejene i april 1861 er "gjennemstukken" to steder for at befordre vandløb, og man har "jævnet adskillige køresteder og vejspor “, og i november samme år er der ved en anden vej anbragt en ny vandhæk, ${ }^{21}$ samt nedlagt fem siiler $i$ skoven (gennemløb ved en vej, dige el. lign.). Til disse er brugt ialt 72 stk. brændte rør á 4 skilling stykket. Og næste år har man indsat hele fire vandhække i den søndre side af skovdiget samt oprenset hovedgrøften mellem afd. I og II, det vil sige grøften langs vejen, der fra Frederiksgård fører østpå gennem skoven. Og samme år er der sket en planering af "Skovveien mod Øst", hvorved sandsynligvis menes den samme vej. Dette arbejde har kostet 5 Rdl. 2 Mark.

Af hensyn til de meget fugtige forhold i den sydlige del af skoven var det her nødvendigt med et særligt effektivt grøftesystem. Denne opgave tog man fat på i 1863. Da begyndte gravningen af den store grøft, som bliver hovedledningen for afvandingen af den sydlige del af skoven, idet den fører vandet fra vest mod øst og ud af skoven i det sydøstlige hjørne; d.v.s. den grøft, som i vore dage kaldes Moskærgrøften. Af en regning for august 1863 ses, at der er gravet 76 roder (ca. $350 \mathrm{~m}$ ) af den nye vandledning ud fra Draved skov. ${ }^{22} \mathrm{En}$ anden regning fra sommeren 1863 meddeler, at der er benyttet en "vandmølle til bortledning af vandet fra den under arbejde værende nye vandledning “. Betegnelsen "vandmølle" synes misvisende, idet der udtrykkeligt tales om, at det er et apparat til at skaffe vandet bort fra den nye grøft. Og et andet sted omtales en rende til bortledning af vandet. Der kan altså ikke menes en vanddreven mølle, men simpelthen et hjul, hvorpå der har siddet øseindretninger, og som er drevet ved en eller anden kraftkilde (f.eks. hestekraft), således at vandet, der generede ved grøftens gravning, kunne fjernes.

Anlægget af Moskærgrøften var et meget stort arbejde og stod på gennem flere år. I efteråret 1863 er således gravet et stort stykke henover Frederiksgårds mark, omtrent samtidig er der inde i skoven gravet $423 / 4$ roder (ca. $194,50 \mathrm{~m}$ ). Endvidere fortsætter arbejdet endnu i 1866.

Ligeledes fra 1866 fortæller en regning om vejenes vedligeholdelse. Det fremgår heraf, at en af dem er afgravet og planeret og udbedret med ris. Om en anden vej hedder det, at den er fuldstændig istandsat med faskiner. 
Betaling for arbejdet $i$ skoven

Af de mange regninger ses ikke blot, hvilke arbejder der er udført, men også hvad der er betalt for dem. Det var, set med nutids øjne, uhyre beskedent. En almindelig dagløn for hårdt arbejde som grøftegravning er 4 mark. I nogle tilfælde er arbejdet udført som akkord, og betalingen kunne da være 7 skilling pr. rode, medens der i andre tilfælde, hvor kravene åbenbart har været større, er betalt med 25 skilling pr. rode.

For gravning af Moskærgrøften, som var meget bred og dyb, og hvor arbejdet $i$ det hele var ualmindelig vanskeligt, ydedes den fyrstelige betaling af indtil 5 mark pr. rode.

At betalingen virkelig har været særdeles ussel, også målt med datidens alen, fremgår af et brev, hvoraf der kun findes et brudstykke, som hverken er dateret eller underskrevet, men som tilsyneladende er skrevet med Andresens skrift. Det meddeles heri skovrideren, at der "mellem 6. og 7. Hugst" er opgravet en grøft; men »det ville være ubilligt at forlange, om Heinrich alene skulle udføre dette sardeles slet betalte grøftearbejde og har jeg desårsag sat flere $\mathrm{i}$ arbejde og forventer således endnu i denne måned at få størstedelen fuldendt $\ll$.

\section{De gamle skovdiger}

Af skovens gamle diger skal nogle få mere markante omtales:

I afsnittet "Draved Skov i middelalderen “ omtaltes "Draved Dige «, (fig. 5) som formentlig svarer til det, de gamle kaldte $\# Æ$ skovdige“ og som nok er begrænsningen af den gamle skov. Kun rester af diget ses i vore dage, og de ligger som sagt de fleste steder et stykke uden for skoven. Bedst bevaret er det mod vest, hvor det undtagelsesvis på en kort strækning følger skovkanten.

Ligeledes er "Ulvevolden « tidligere nævnt. I den sydlige del af skoven, ikke langt fra sydhegnet og omtrent parallelt med dette, ses en gammel vold, som måske kan være "Ulvevolden «.

Fra Frederiksgård løber $\mathrm{i}$ sydlig retning, og med drejning mod vest, et gammelt dige, der kan spores helt ud til skovkanten, og hvis oprindelse ligeledes fortaber sig i middelalderen. Sammen med en anden gammel vold nord for Frederiksgård og tildels med »Æ skovdige« danner det en sluttet helhed, som muligvis har afgrænset den vestlige del af skoven og synes at være zldre end »Æ skovdige“. Formålet kan man kun gisne om; måske hegn for svin eller kvæg.

Frederiksgårddiget findes mærkeligt nok ikke på det ældste skovkort (1780), til trods for, at det må have eksisteret på det tidspunkt, men det har vel allerede da været gammelt og mere eller mindre sammenfaldent, så man ikke har været interesseret $i$ at tage det med ved opmålingen. Derimod er det 
stående træer, så der forestod et stort rydningsarbejde, før jorden kunne tages under plov.

Kun kort tid havde Lorenz Paulsen lejlighed til at glæde sig over sin nye ejendom, idet han ifg. kirkebogen døde den 30 . sept. 1786, 63 år gammel. ${ }^{23}$ Kort efter bliver Frederiksgård solgt, og $\mathrm{i}$ den anledning udarbejdes en fortegnelse over de til gården hørende parceller (aug. 1787). I tilslutning hertil findes endvidere en redegørelse for, hvor der endnu findes skov på ejendommen, med angivelse af træernes antal, men uden artsspecifikation. Ialt er der tale om 2153 træer, men da der intet angives om størrelse eller mål, giver det trods alt kun et ringe begreb om, hvor megen trævækst der endnu på næunte tidspunkt fandtes på Frederiksgårds jorder. ${ }^{24}$

Imidlertid kan man sikkert gå ud fra, at endnu i slutningen af 1780'erne har kun en ringe del af gårdens tilliggende været under plov. Arbejdet med rydning og opdyrkning af de dertil egnede arealer synes dog at være skredet jæunt fremad i de følgende år, og i tidens løb sker en ret omfattende udstykning.

Ifølge Trap (1930) udskilles i 1799 den jord nordøst for skoven, som nu er delt mellem flere småsteder, der går under navnet Eltoft. I 1814 fortsættes udstykningen med Tinggård ligeledes nordøst for skoven og 1857 med Lydiksgård sydvest for denne. Det resterende areal deltes endnu engang i 1907, hvorved den nuværende Skovgård, som oprindelig kaldtes Hoheneck, opstod.

\section{Skovens drift i nyere tid}

\section{Plantningsarbejde}

I de ældste tider måtte Draved skov, ligesom andre naturskove, forny sig ved selvsåning. Regelmæssig plantning og hugst var noget ganske ukendt. Hvis et træ faldt i skoven - på grund af ælde eller måske fældet af mennesker - og der således opstod et "åndehul«, gik der ikke mange år, før lysningen fyldtes af opvakst, og som tiden gik, tog et eller nogle få af de opvoksende træer føringen, og til sidst lukkedes mhullet «. På den måde kom skoven dels til at bestå af flere træarter imellem hinanden og dels af træer af meget forskellig alder.

Hvornår plantningsarbejdet kom $\mathrm{i}$ gang vides ikke med bestemthed, men sandsynligt er det, at det skete i begyndelsen af 1800-tallet, hvor den nuværende skov var blevet indhegnet og det mere rationelle skovbrug begyndte. - Draved skov blev efterhånden i stand til at forsyne sig selv med ungtræer og der høres både om indsamling af "frø» og om flere planteskoler $\mathrm{i}$ skoven. 


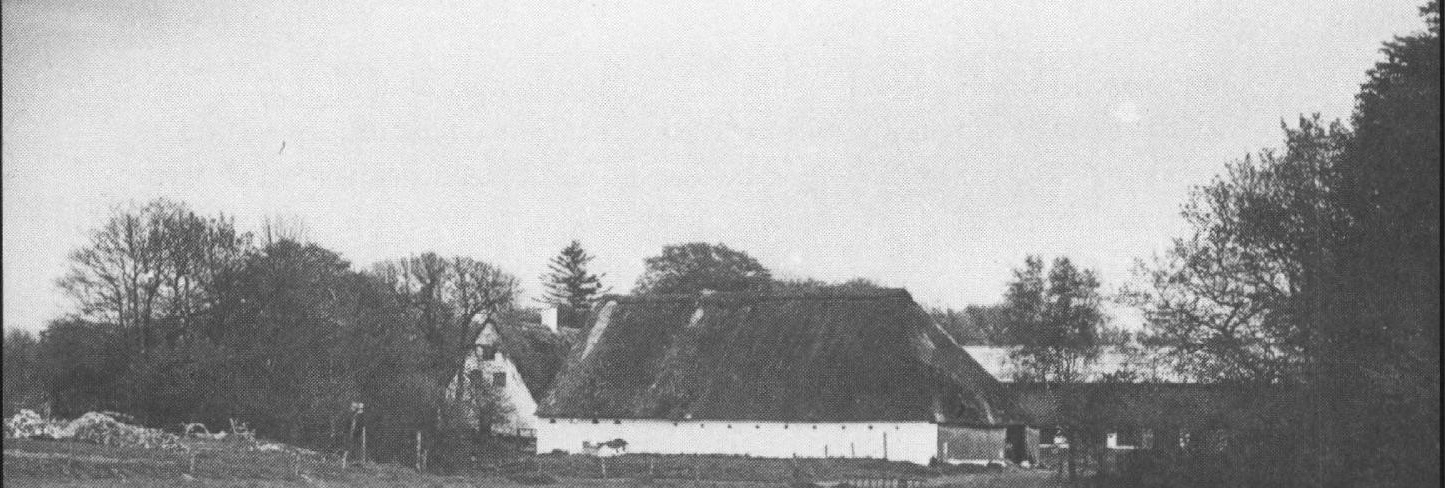

Fig. 6. Frederiksgärd set fra nordvest. Pä billedet bemarkes isar den gamle ladelange med de små vinduer og det afvalmede tag. Langen i baggrunden er af nyere dato. (H. Krog fot. maj 1957).

Så tidligt som i 1824 får den daværende skovfoged Warner besked om at udlevere 2000 stk. birkeplanter til justitsråd Møller, men det fremgår ikke klart, hvorvidt der er tale om planter fra en planteskole, eller om det blot drejer sig om selvsåede træer i skoven. Og fra efteråret 1829 foreligger et brev om indsamling af træfrugter. Da det er stilet til Warner, som stadig var skovfoged i Draved, kan man nok - selvom Draved skov ikke direkte nævnes - gå ud fra, at det er den, det drejer sig om. Der sker åbenbart en årlig indsamling af agern og ellefrugter. En sådan indsamling må vel tænkes at foregå med henblik på udsåning i planteskoler, som skoven på den tid formentlig har haft en eller flere af, selvom det ikke absolut behøver at være tilfældet.

I 1843 omtales der for første gang direkte en planteskole i Draved"Drauitter Baumschule«, men det er først efter at Peter Andresen 1851 har overtaget skovfogedembedet, at der kommer fart i planteskolearbejdet og ligeledes i anlæggelsen af nykulturer. I de følgende år kan der således spores et stort salg fra Draved af ungplanter til de omkringliggende skove.

Ligesom lønnen for grøftearbejdet i Draved skov var meget ringe i midten af forrige århundrede, således også med de fleste andre arbejder i skoven, og det hårde slid i planteskolerne dannede ingen undtagelse. Andresen som øjensynlig ser på arbejdernes tarv, søger i midten af 1850 'erne om at måtte forhøje deres dagløn. Antagelig har han fảet afslag, i hvert fald i første 
omgang, idet det ses, at han senere har indsendt en ny anmodning derom. Om det førte til en mærkbar lønforhøjelse er måske tvivlsomt; i hvert fald ses af et regnskab fra maj 1861 hvor dårligt selv hårdt jordarbejde blev betalt i de tider. Ved anlæg af en ny planteskole er 44 kvadratroder kulegravet, d.v.s. gravet til en alens dybde, og derfor er betalt $1 \mathrm{Rd}$. pr. kvadratrode, ${ }^{25}$ og for påkørsel af fem læs mergel betales ialt $1 \mathrm{Rd}$. og 64 skilling.

\section{Skovens sammensatning}

Selve skovens sammensætning kan følges via en række driftsplaner, samt gennem årlige skovregnskaber, der kan føres tilbage til slutningen af $1700-$ tallet. I en driftsplan fra 1839 meddeles, at skoven overvejende består af birk blandet med andet blødtræ og bøg. Desuden fandtes en del gamle ege og bøge, og på højere bund dominerede små bøgebevoksninger. Planen går iøvrigt ud på, at skoven skal drives i mellemskovdrift eller blandet drift, hvorved egene skulle danne højskoven, medens underskoven skulle dannes af blødtræet med birken som vigtigste komponent. Denne driftsform virkede indtil 1863, da den blev underkastet en revision, som gik ud på, at halvdelen af arealet skulle overgå til nåletræ, der $\mathrm{i}$ højere grad end løvtræ kunne anvendes til gavnstammer. Som grund angives, at brændetræ, som følge af egnens store tørvemoser, var vanskeligt at afsætte. En ny plan fra 1868 bestemmer, at nåleskov helt skal afløse løvtræerne, som kun bør anvendes for at formindske vindbrudsfaren. ${ }^{26}$ Disse bestemmelser blev dog ikke gennemført, og senere driftsplaner er til alt held gået $\mathrm{i}$ andre retninger, så at $\mathrm{i}$ vore dage endnu store dele af skoven er bevaret som løvskov.

Op mod vor egen tid er der sket store ændringer i egnen omkring Draved. Medens man for blot en menneskealder siden måtte færdes ad smalle og ofte opblødte spor, som bugtede sig ud over mose og hede, foregår trafikken nu ad gode, solide veje, og størstedelen af de omkring skoven liggende lyng- og mosearealer er nu opdyrkede. - Og i selve skoven har den moderne tid sat sine spor, bl.a. i form af plantning af træarter, som ikke er oprindeligt hjemmehørende her. Det er derfor af stor naturvidenskabelig betydning, at omfattende dele af skoven er blevet fredet, således at dens særpræg ikke går tabt, men kan bevares for eftertiden.

\section{Efterskrift}

Artiklen, fremlagges her hovedsageligt efter et manuskriptudkast fra 1974, mens der dog også i mindre omfang er taget hensyn til en foreløbig fremstilling af samme emne fra 1957. Manuskriptet var tænkt som indledende afsnit i et større naturvidenskabeligt arbejde om Draved skov og dens omgivelser, men da det skønnes, at flere af de indsamlede oplysninger også har lokalhistorisk interesse, er den her foreliggende sammenstilling forsøgt på trods af, at den af næunte årsager nok vil virke lidt 
usammenhængende. Medarbejdere ved Moselaboratoriet, Danmarks Geologiske Undersøgelse, takkes for beredvillig hjælp ved manuskriptgennemgang og fremskaffelse af illustrationer.

Steen Wulff Andersen, Haderslev Museum

\section{KILDER}

Vasentlige kilder for afhandlingen som helhed er:

Rigsarkivet,

Tønder amt, mappe 1, Gemarkungsakten aus dem Schleswigschen Landkommissariat;

De sønderjyske fyrstearkiver, de gottorpske hertuger, D 25 I, 1, jordebog for Løgumkloster amt 1607.

Landsarkivet for de sonderjyske landsdele, Abenrä

Aflevering fra Kiel, C V 1, nr. 95 og C V 3 nr. 214;

Løgumkloster amtstuearkiv 1846-68 og Tønder amtsarkiv 1849-67 (om skovbrandene);

Åbenrå skovriderdistrikts arkiv 1821-72, 1847-80 (om grøfterne).

\section{NOTER OG HENVISNINGER IØVRIGT}

1. Der rettes en tak til fru G. Vang Nielsen og afdelingsgeolog, cand. mag. P. Ingwersen, der har hjulpet med vanskelige passager og ord i arkivmaterialet. Også en tak til Danmarks Geologiske Undersøgelse, som har muliggjort flere ophold i arkiver, og til Carlsbergfondet, hvis støtte til affotografering muliggjorde et mere indgånde studium af dokumenterne.

2. Jvf. Danmarks Natur, bd. I, s. 417, Politikens Forlag, 1967. S. Jørgensen: Skovrydning med flintøkse. Fra Nationalmuseets Arbejdsmark 1953.

3. A. Andersen, m.f1.: Ekskursion til Senderjylland 5. - 7. august 1965. - Medd. Dansk Geologisk Forening, bd. 16. hf. 2, Kbh. 1966. H. Kapel: Nye fund fra ældre stenalder i Sønderjylland, Sjy. Årb. 1958, s. 223-33; samme: En uforstyrret stenalderboplads ved Draved, Sjy. Mskr. 1959. s. 161-66; samme: En ny boplads fra ældre stenalder i Kongens Mose, Fra Haderslev amts Museum 1963, s. 14-19; samme: Nyere arkæologiske undersøgelser i Tønder og Åbenrå amter, Sjy. Årb. 1964, s. 253-60; samme: Stenalderfolket ved Draved Sø, Skalk 1965, 5.

4. Sønderjyske Stednavne III, 1933

5. R. Mortensen: Jyske Tørvemoser m.m. 1789. - Hedeselskabets tidssk. 77. årg. s. 80 Viborg 1956.

6. Alle de i dette afsnit omtalte middelalderlige breve findes i J. Langebek: Scriptores rerum danicarum, bd. 8 (Løgumbogen), Hauniae 1834.

7. Jordstykke uden for fællesjorden. (A. Kalkar: Ordbog til det ældre danske sprog. - Kbh. 1881-1918, bd. IV, s. 183).

8. "Otting betyder ottendedel og må oprindelig (anvendt som jordemål) betegne en ottendedel af et bol. Senere blev imidlertid den senderjyske ottinginddelings forhold til bolet noget udvisket. (Sønderjyske Stednavne 1, 1944, s. XLVII.)

9. Bl.a. Jan Markussen, den tidligere ejer af Skovgård, sydvest for skoven.

10. D.v.s. Nr. Løgum sogn.

11. En speciel skat, som blev udskrevet, når kongen bortgiftede én af sine døtre.

12. R. Mejborg: Nordiske Bøndergårde $\mathrm{i}$ det XVIde, XVIIde og XVIIIde Århundrede. I. Slesvig, København 1892. - Andetsteds opgives dusørerne til: 6 rd. for en voksen ulv og 2 rd. for et ungt dyr.

13. Fr. Mager: Entwicklungsgeschichte der Kulturlandschaft des Herzogtums Schleswig in historischer Zeit. I. - Breslau 1930. 
14. A. Olrik: Prove af Sønderjyllands Folkesagn, Sjy. Årb. 1900, s. 229-237.

15. Mejborg, o.a.a.

16. Louis Bobé: Bidrag til Tønder Bys og Hostrup Sogns Historie 1540-1692. - Sjy. Årb. 1905, s. 99-109.

17. LA. Áb., C V 3, nr. 224 (Afl. fra Kiel).

18. Rigsarkivet. Gottorper arkiv D 25 I, 1 jordebog for Logumkloster amt 1704.

19. Selvom det var fristende, var det ikke altid tilrådeligt at lade kvæget græsse i skoven. De gamle fortalte, at køerne kunne blive syge, ja dø, hvis de åd en bestemt plante, en padderok (vistnok kær-padderok, Equisetum palustre). Den kaldtes ligefrem med det tyske dialektnavn, Kodoot, på dansk simpelthen Kodød eller Kvagdød. Denne ulempe skyldes dog ikke selve planten, men en svamp, som snylter på den.

20. Peter Andresen er ejer af Frederiksgård omkring 1800. "Hale«: mest brugt om langstrakt jordstykke, her altså = langstrakt skovparti. Også gården(e) i Faurby har åbenbart haft en særlig skovpart; på det gamle skovkort fra 1780 læses navnet "Faurby Hahl«.

21. Et gitter til at holde visne blade og lign. tilbage, når vandet f.eks. løber under vejen.

22. Måleenheden 1 rode kunne variere lidt fra landsdel til landsdel, men har man benyttet hamburgermålet som tilfældet er på skovkortet 1780 , vil en rode være lig ca. $4,58 \mathrm{~m}$.

23. LA Åb, Logumkloster kirkebog 1786.

24. R. Mortensen jvf. note 5.

25. Ca. $21 \mathrm{~m}^{2}$ (iflg. Sv. Aakjær: Nordisk Kultur bd 30, 1936) forudsat at det drejer sig om hamburgsk mål, som tilfældet er på skovkortet af 1780 .

26. LA Åb, Lindet skovdistrikts arkiv, (redegørelse for bl.a. diverse driftsplaner i 1800-tallet). 